\title{
EXPLORATORY ANALYSIS OF RARE AND NOVEL VARIANTS IN MEXICAN PATIENTS DIAGNOSED WITH SCHIZOPHRENIA AND DEMENTIA
}

\author{
José J. Martínez-Magaña ${ }^{1}$, Alma D. Genís-Mendoza ${ }^{1,2}$, Vanessa González-Covarrubias 3 , \\ Janet Jiménez-Guenchi ${ }^{4}$, Aidé G. Galindo-Chávez ${ }^{4}$, Andrés Roche-Bergua ${ }^{4}$, Carlos Castañeda- \\ González $^{4}$, Nuria Lanzagorta ${ }^{5}$, Xavier SOberón $^{3 *}$, Humberto Nicolini ${ }^{1,5 *}$ \\ ${ }^{1}$ Genomics Laboratory of Psychiatric and Neurodegenerative Diseases, Instituto Nacional de Medicina Genómica, \\ Mexico City; ${ }^{2}$ Psychiatric Care Services, Hospital Psiquiátrico Infantil "Juan N. Navarro", SSA, Mexico City; \\ ${ }^{3}$ Pharmacogenomics Laboratory, Instituto Nacional de Medicina Genómica, Mexico City; ${ }^{4}$ Psychiatric Care Services, \\ Hospital Psiquiátrico "Fray Bernardino Alvarez," SSA, Mexico City; ${ }^{5}$ Grupo de Estudios Médicos y Familiares, Mexico \\ City, Mexico.
}

\begin{abstract}
Background: Schizophrenia (SCZ) and dementia, often related, are two of the most common neuropsychiatric diseases; epidemiological studies have shown that SCZ patients present a 2-fold increased risk for dementia compared to non-schizophrenic individuals. We explored the presence of rare and novel damaging gene variants in patients diagnosed with late-onset dementia of Alzheimer's type (DAT) or SCZ. Methods: We included 7 DAT and 12 SCZ patients and performed high-depth targeted sequencing of 184 genes. Results: We found novel and rare damaging variants in 18 genes in these Mexican patients. Carriers of these variants showed extreme phenotypes, including, treatment-resistant SCZ or cognitive decline. Furthermore, we found a variation on $A B C C 1$ as a possible link between psychosis and cognitive impairment. Discussion: As an exploratory analysis, we report some interesting variations that should be corroborated in larger sample size studies. (REV INVEST CLIN. 2019;71:246-54)
\end{abstract}

Key words: Next-generation sequencing. Dementia. Schizophrenia. Novel variants. Rare variants.

\section{INTRODUCTION}

Neuropsychiatric disorders affect approximately $30 \%$ of the population worldwide ${ }^{1-3}$. Schizophrenia (SCZ) and dementia, often related, are two of the most common neuropsychiatric diseases ${ }^{4}$, and epidemiological studies indicate that patients diagnosed with
SCZ present a 2-fold increased risk for dementia compared to non-schizophrenic individuals ${ }^{5}$. Unfortunately, the etiology of these complex diseases remains to be fully elucidated. Genome-wide association studies (GWAS) have contributed to explain approximately $12 \%$ of phenotypic variation of these complicated disorders, including SCZ and dementia ${ }^{6,7}$, showing an

Corresponding author:

*Humberto Nicolini or Xavier Soberón Instituto Nacional de Medicina Genómica

Mexico City, Mexico

E-mail: hnicolini@inmegen.gob.mx

xsoberon@inmegen.gob.mx

Received for publication: 27-11-2018

Approved for publication: 06-02-2019

DOI: $10.24875 / R I C .19002923$ 
apparent missing heritability ${ }^{8}$. One approach to find this missing heritability is to investigate rare highlydamaging (RHdv) and novel variants (Nv) which are not routinely considered in GWAS analyses. Several research groups have undertaken this quest using next-generation sequencing (NGS) ${ }^{9}$. One limitation could be that RHdv and Nv are potentially populationspecific $^{10,11}$. The collection of genetic variation in Mexican populations is still an ongoing and incipient endeavor, particularly for RHdv and $\mathrm{Nv}^{12}$. This study aimed to explore by NGS the presence of novel and damaging variants for 184 genes in 19 Mexican patients diagnosed with dementia or SCZ.

\section{METHODS}

\section{Study population}

Nineteen individuals from the Geriatric Clinic at the Psychiatric Hospital "Fray Bernardino Alvarez" and the Group of Medical and Family Studies Carracci in Mexico City, Mexico, were invited between 2011 and 2013 to participate. Of them, seven were diagnosed with late-onset dementia of probable Alzheimer's type (DAT) and 12 with SCZ. All patients were invited to participate and signed informed consent. The study protocol complied with the Helsinki Declaration and was approved by the Ethics and Research Committee at the National Institute of Genomic Medicine (No. IMG/DI/136/2014).

DAT patients filled a demographic questionnaire and were evaluated by a geriatric psychiatrist at the Psychiatric Hospital "Fray Bernardino Alvarez." Dementia was diagnosed based on the DSM-IVR criteria since our study group found memory impairment and at least one other cortical function affected ${ }^{13}$. All the patients had a family history of Alzheimer's disease in at least one, first, or second degree relative, and fulfilled the criteria for probable Alzheimer's diagnosis according to the National Institute of Neurological Disorders and Stroke and the Alzheimer's Disease Related Disorders Association ${ }^{14}$. The patients were evaluated using the following scales: mini-mental state examination (MMSE), NEUROPSI, clock-drawing test, DIPAD, and the clinical dementia rating ${ }^{15-20}$.

Patients with paranoid SCZ were recruited from the Group of Medical Studies Carracci; all patients had a family history of at least one-, first-, or second-degree relative diagnosed with SCZ. Patients were evaluated with a diagnostic interview for genetic studies $^{21}$, which is a structured interview, including the disorders contained in the Axis I of the DSM-IVR. In this respect, little changes have been made in the latest version of DSM for SCZ diagnosis ${ }^{22}$. Furthermore, when the medical record of the patient was available, we included a structured sequence of the response to the consumed medications. We established criteria for treatment-resistance, as previously published ${ }^{23}$. Positive and negative symptoms were evaluated with SAPS and SANS scales, and cognitive function was evaluated with the $M_{M S E}{ }^{24}$. APOE-E4 variant is the most extensively validated among the genetic markers associated with cognitive decline. To consider this variation, all the included individuals (i.e. 7 DAT and 12 SCZ) were negative for the E4 allele of the APOE; the $A P O E$ status was determined by real-time $P C R$, as previously described ${ }^{25}$.

\section{Targeted NGS}

Genomic DNA was extracted from peripheral leukocytes using the Gentra Puregene commercial kit (QIAGEN, USA). We designed synthetic probes for NGS, targeting genes associated with dementia, SCZ, and several pharmacogenetic targets. The selection of genes was based on a literature search for published works reporting an effect of common variations or rare variants in SCZ, dementia or drug response to different antipsychotics or antidementia drugs ${ }^{6,7,26-36}$; a list of the captured genes is reported in Supplementary Table 1 . Gene capture was performed using the Haloplex target enrichment system (Agilent Technologies, USA) with $1.51 \mathrm{Mb}$ with 40754 amplicons. Sequencing libraries were generated according to the manufacturer's protocol (version D.5, May 2013). Briefly, all DNA samples (a total of $225 \mathrm{ng}$ for each sample) were digested with 8-paired restriction enzymes; fragmentation pattern was analyzed in a 2100 Bioanalyzer (Agilent Technologies, USA). DNA fragments were hybridized with Haloplex synthetic probes for library enrichment, and adapters were ligated by PCR. Then, library qualities for fragment size and concentration were assessed using a 2100 Bioanalyzer, as previously described ${ }^{37}$. Sequencing was performed using a NextSeq500 system (Illumina, USA), aiming for $200 x$ depth coverage in paired-end reads. 
Table 1. Rare or novel damaging variants detected in patients diagnosed with Dementia of the Alzheimer's type

\begin{tabular}{|c|c|c|c|c|c|}
\hline Variant & dbSNP & Gene & $\begin{array}{l}\text { Reference } \\
\text { MAFA }^{\mathrm{A}}\end{array}$ & Mendelian ${ }^{B}$ & Complex ${ }^{\mathrm{c}}$ \\
\hline \multicolumn{6}{|l|}{ Missense variants } \\
\hline $\begin{array}{l}\text { NP_004792.1: } \\
\text { p.Pro108Ala }\end{array}$ & rs199784029 & $N R X N 1$ & 0.0008 & $\begin{array}{l}\text { Pitt-Hopkins-like } \\
\text { syndrome-2 }{ }^{55,56}\end{array}$ & $\begin{array}{l}\text { Autism spectrum } \\
\text { disorder }{ }^{60-64} \text { and } \\
\text { schizophrenia }^{65}\end{array}$ \\
\hline $\begin{array}{l}\text { NP_742054.1: } \\
\text { p.Val33Met }\end{array}$ & rs765679790 & $\mathrm{KCNH} 2$ & 0.000008 & Long QT Syndrome $2^{57,58}$ & $\begin{array}{l}\text { Schizophrenia treatment } \\
\text { response } \\
\text { intellectual coefficient } \\
\text { in schizophrenia }^{68}\end{array}$ \\
\hline $\begin{array}{l}\text { NP_000515.2: } \\
\text { p.Ala155Gly }\end{array}$ & rs145641566 & HTR $1 A$ & 0.0005 & $\begin{array}{l}\text { Periodic fever, menstrual } \\
\text { cycle-dependent }{ }^{59}\end{array}$ & $\begin{array}{l}\text { Alcohol and nicotine } \\
\text { dependence } 69,70 \\
\text { and Alzheimer's disease } \\
\text { with alcohol dependence } \\
\text { comorbidity }^{69}\end{array}$ \\
\hline $\begin{array}{l}\text { NP_001748.1: } \\
\text { p.Gly195Arg }\end{array}$ & rs146758729 & CBR1 & 0.0015 & NR & Drug toxicity ${ }^{71,72}$ \\
\hline \multicolumn{6}{|c|}{ Non-coding variants } \\
\hline $\begin{array}{l}\text { NT_187607.1: } \\
\text { g.1782677C>T }\end{array}$ & rs28363996 & $A B C C 1$ & 0.0003 & NR & Drug resistance ${ }^{73-76}$ \\
\hline
\end{tabular}

AReference MAF: Minor allele frequency reported in the GnomAD or the 1000 Genomes Project. BLoF variant reported to be disease-causing of Mendelian inheritance disorder. ${ }^{C}$ Common or rare variants reported to be associated to neuropsychiatric disorder. NR: Not reported.

\section{Bioinformatic analyses}

First, for quality control, we utilized trimmomatic to eliminate reads with a quality score Phred-QS $<25$ and length below 55 bp; indexes, adaptors, and 5 bp at both read ends were trimmed according to general practices $^{38}$. We then aligned reads to the human genome using BWA ${ }^{39}$ and SMALT with GRCh $37 / \mathrm{hg} 19$ as reference ${ }^{40}$. InDel realignment, base recalibration, and variant calling were done following the GATK bestpractices recommendations ${ }^{41,42}$. HaplotypeCaller was used for SNV detection, and copy number variants (CNV) were detected using the pipeline implemented by $\mathrm{XHMM}^{43}$. A total of 1274 variants were called by both aligners, which were used for the following analyses. Variants were confirmed visually in the integrative genomic viewer IGV, and also, annotated using dbSNP version $147^{37,44}$.

\section{Analysis of rare and novel damaging variants selection}

Variants were registered if detected in at least one SCZ or DAT patient, as heterozygous or homozygous. Variants were annotated utilizing different databases including: dbSNP, OMIC, ClinVar, GnomAD, rebuild, and 1000 Genomes, with Variant Effect Predictor ${ }^{45}$, allowing the prediction of the functional impact, with queries to different algorithms and databases (SIFT, Polyphen-2, FATHMM, CADD, gene splicer, and splice region) ${ }^{46-53}$. As possible pathogenic variants, we selected loss-of-function (LoF) variants (frame shift, stop gained, splice-site acceptor, and splice-site donor) and missense variants if the three algorithms predicted the variants to be damaging (i.e., SIFT, FATHMM, and polyphen-2), and coding synonymous variants and non-coding variants were selected if the CADD score was higher than 25 (CADD). After filtering these variants, we included all the $\mathrm{Nv}$, and for previously reported ones, we only included rare mutations (minor allele frequency $<0.1 \%$ ) using the Genome Aggregation Consortium (GnomAD) and the 1000 Genomes projects databases as reference for population allelic frequency. ClinVar, OMIM (Online Mendelian Inheritance in Man), and an own search in PubMed databases were used as reference for the clinical significance and disease-associated variants. Furthermore, a novel variation ( $\mathrm{Nv}$ ) was considered when it had not been reported. We used the Human Genome Variation Society (HGVS) nomenclature using 
the web-tool mutalyzer 54 , and included the "rs" dbSNP (version 147) identifier for the nonNv.

\section{RESULTS}

\section{Summary of the total detected variants in the sample}

Bioinformatic analyses detected 1274 variants on 184 genes, with an average depth of 96x (range: $55 \mathrm{X}-120 \mathrm{X}$ ), and $91.2 \%$ coverage. Of these, 1148 were SNVs, 126 indels, and only one CNV on RELN gene. A total of 149 variants ( $11.7 \%$ ) were located in coding regions and 1125 (88.3\%) in non-coding regions. Frequency analyses showed that more than half of all variants (735 variants) were common (minor allele frequency $>5 \%$ ). In total, we also identified $86 \mathrm{Nv}$ not previously reported. The genes with the highest number of Nv were PTGER3 (21 Nv), SLC6A3 (5 Nv), and ADD1 (5 Nv).

\section{Rare and Nv in patients with DAT}

In three of seven DAT patients (42.9\%), we detected five damaging variants in five genes (NRXN1, HTR1A, $K C N H 2, C B R 1$, and $A B C C 1$ ) (Table 1). Novel or LoF variations were not observed. Four variants were missense: NRXN1 (p.Pro108Ser), HTR1A (p.Ala155Gly), KCNH2 (p.Val33Met), and CBR1 (p.Gly195Arg), and one intronic $A B C C 1$ (g.1782677C>T). LoF variation in three genes (NRXN1,KCNH2, and HTR1A) has been reported to be causal of some syndromes with Mendelian inheritance type (Pitt-Hopkins-like syndrome-2, Long QT Syndrome 2, and menstrual cycledependent periodic fever), while $C B R 1$ and $A B C C 1$ have been reported in drug response. Furthermore, common variation in genes $N R X N 1$ and $K C N H 2$ has been previously associated to neuropsychiatric disorders (SCZ, autism spectrum disorder, and drug abuse and dependence), and only common variation on HTR1A has been previously associated to DAT. One single DAT patient, DAT 1 , carried three of the seven damaging variants, on NRXN1, KCNH2, and $A B C C 1$. This patient obtained the lowest scores in the MMSE $=7$ (i.e., affecting almost all his cognitive areas). A summary of some sociodemographic and clinical characteristics of patients carrying the variants is shown in Supplementary Table 2.

\section{Rare and $\mathrm{Nv}$ in patients with SCZ}

In schizophrenic patients, we identified 13 variants on 13 genes: ANK2, CYP3A4, RELN, HTR7, DISC1, TYMS, CYP2B6, MTHFR, NRG1, SLC6A5, BDNF, GRIN2B, and $A B C C 1$ (Table 2). Of these, four were LoF on $A N K 2$, CYP3A4, RELN, and HTR7; three were missense on DISC1, TYMS, and CYP2B6; and six were coding synonymous or non-codng on MTHFR, NRG1, SLC6A5, $B D N F, G R I N 2 B$, and $A B C C 1$. We identified six Nv, which represented almost half of all variants detected for this patient group. In these patients, 10 of the 12 (83.33\%) included individuals was a carrier of a damaging variant. Previously, LoF variants in ANK2, RELN, SLC6A5, MTHFR, and GRIN2B have been reported to cause syndromes with Mendelian inheritance (Table 2). Interestingly, the patient carrier of the variants in DISC1 had the lowest cognitive function (mini-mental state $=15$ ), and a patient carrier of the LoF in $C Y$ P3A4 had treatment-resistant SCZ. A summary of genetic variations and clinical and sociodemographic data of patients with SCZ are presented in Supplementary Table 3.

\section{DISCUSSION}

Here, we present a next-generation genome sequencing analysis to explore the existence of rare and novel damaging variants in patients with $\mathrm{SCZ}$ or DAT. Clearly, one of the main limitations of this study is the low number of patients included. However, as an exploratory study, we obtained interesting results that could prompt future studies with larger sample sizes. To the best of our knowledge, there are no reports using NGS to identify rare and novel gene variation for neuropsychiatric disorders in Mexican patients.

Our analyses showed that almost $10 \%$ of the targeted genes were carriers of one rare or novel damaging variant. For example, genes coding for drug-metabolizing enzymes (DME) (CBR1, CYP3A4, TYMS, CYP2B6, and MTHFR), and genes involved in neurodevelopmental processes (ANK2, RELN, DISC1, NRNX1, $N R G 1$, and $B D N F$ ) were the two main pathways observed in this study with relevant variation in these patients. Variants on genes ANK2, RELN, and NRNX1 have been associated with some syndromes with Mendelian inheritance affecting neurodevelopmental 
Table 2. Rare or novel damaging variants detected in patients diagnosed with Schizophrenia

\begin{tabular}{|c|c|c|c|c|c|}
\hline Variant & dbSNP & Gene & $\begin{array}{l}\text { Reference } \\
\text { MAFA }^{\text {MAF }}\end{array}$ & Mendelian ${ }^{B}$ & Complex ${ }^{c}$ \\
\hline \multicolumn{6}{|l|}{ LoF } \\
\hline $\begin{array}{l}\text { NP_001139.3: } \\
\text { p.Thr3457Hisfs }\end{array}$ & rs750143580 & ANK2 & 0.00006 & $\begin{array}{l}\text { Long QT syndrome } 4^{77} \\
\text { and Cardiac Arrythmia } \\
\text { (Ankyrin-B-related) }{ }^{78}\end{array}$ & $\begin{array}{l}\text { Bipolar disorder with } \\
\text { binge-eating } 89\end{array}$ \\
\hline $\begin{array}{l}\text { NC_000007.13: } \\
\text { g.103130984- } \\
103474463 \mathrm{del}\end{array}$ & NR & RELN & NR & $\begin{array}{l}\text { Lissencephaly } 2^{79,80} \\
\text { and Familial Temporal } \\
\text { Lobe Epilepsy } 7^{81}\end{array}$ & $\begin{array}{l}\text { Schizophrenia, autism } \\
\text { spectrum disorder }{ }^{90} \text { and } \\
\text { Alzheimer's disease }\end{array}$ \\
\hline $\begin{array}{l}\text { NP_059488.2:p. } \\
\text { Pro488Thrfs }\end{array}$ & rs67666821 & CYP3A4 & 0.0002 & NR & $\begin{array}{l}\text { Treatment response in } \\
\text { schizophrenia }{ }^{28}\end{array}$ \\
\hline $\begin{array}{l}\text { NC_000010.10: } \\
\text { g.92617169- } \\
92617170 \text { ins }\end{array}$ & NR & HTR7 & NR & NR & Alzheimer's disease ${ }^{93}$ \\
\hline \multicolumn{6}{|l|}{ Missense variants } \\
\hline $\begin{array}{l}\text { NP_001158010.1: } \\
\text { p.Arg418His }\end{array}$ & rs144959108 & DISC1 & 0.0007 & NR & $\begin{array}{l}\text { Schizophrenia } 94,95 \text { and } \\
\text { Alzheimer's disease }{ }^{70}\end{array}$ \\
\hline $\begin{array}{l}\text { NP_001062.1: } \\
\text { p.Gly246Ala }\end{array}$ & NR & TYMS & NR & NR & Alzheimer's disease ${ }^{96}$ \\
\hline $\begin{array}{l}\text { NP_000758.1: } \\
\text { p.Lys139Glu }\end{array}$ & rs12721655 & CYP2B6 & 0.0023 & NR & Nicotine dependence ${ }^{97}$ \\
\hline \multicolumn{6}{|c|}{ Coding synonymous and non-coding variants } \\
\hline $\begin{array}{l}\text { NP_001305298.1: } \\
\text { p.Ala282= }\end{array}$ & rs77029901 & SLC6A5 & 0.0003 & Hyperekplexia 382,83 & Schizophrenia ${ }^{98}$ \\
\hline $\begin{array}{l}\text { NP_005948.3: } \\
\text { p.Thr139= }\end{array}$ & rs2066466 & MTHFR & 0.0032 & $\begin{array}{l}\text { Homocystinuria due } \\
\text { to MTHFR deficiency }{ }^{84}\end{array}$ & $\begin{array}{l}\text { Neural tube defects } 99,100 \\
\text { and schizophrenia101,102. }\end{array}$ \\
\hline $\begin{array}{l}\text { NC_000012.11:g. } \\
13769306 \mathrm{G}>\mathrm{A}\end{array}$ & NR & GRIN2B & NR & $\begin{array}{l}\text { Autosomal dominant } \\
\text { mental retardation }{ }^{85-87} \\
\text { and early infantile } \\
\text { epileptic } \\
\text { encephalopathy }{ }^{85,88}\end{array}$ & $\begin{array}{l}\text { Schizophrenia and autism } \\
\text { spectrum disorder }\end{array}$ \\
\hline $\begin{array}{l}\text { NC_000008.10:g. } \\
32405771 T>C\end{array}$ & NR & $N R G 1$ & NR & NR & Schizophrenia ${ }^{61,104-107}$ \\
\hline $\begin{array}{l}\text { NC_000011.9: } \\
\text { g. } 27722838 \mathrm{~A}>\mathrm{G}\end{array}$ & rs79141432 & $B D N F$ & 0.0024 & NR & Schizophrenia ${ }^{108}$ \\
\hline $\begin{array}{l}\text { NC_000012.11: } \\
\text { g.16228314T>C }\end{array}$ & NR & $A B C C 1$ & NR & NR & Drug resistance ${ }^{73-76}$ \\
\hline
\end{tabular}

AReference MAF: Minor allele frequency reported in the GnomAD or in the 1000 Genomes Project. ${ }^{B}$ LoF variant reported to be disease-causing of Mendelian inheritance disorder. ' Common or rare variants reported to be associated to neuropsychiatric disorders. NR: No reported. LoF: Loss-of-function variants.

mechanisms, which suggests that they may have a strong influence on the etiology of DAT or SCZ. The overall effect of these variants on the etiology of neuropsychiatric disorders is still under study, although some hypotheses have been proposed. For instance, a recent WES and WGS analysis of neuropsychiatric patients has proposed that an increase of damaging variants on these genes could decrease the age of Alzheimer's onset ${ }^{109}$, and that the age of onset of SCZ and autism-spectrum disorders could be influenced by the accumulation of de novo variants in genes involved in neurodevelopmental processes $^{110,111}$.

The effect of DME on brain processes has been understudied. Nevertheless, some, including CYP1A, 
CYP2B, CYP2C, and CYP3A, have been functionally linked to brain development ${ }^{112,113}$. Our observations regarding DME include that among schizophrenic patients, two were carriers of the CYP3A4*20 (rs67666821) allele as homozygous, and this variant was present in a patient with treatment-resistant $\mathrm{SCZ}^{23}$. CYP3A4*20 is an allele previously identified in the Brazilian population ${ }^{114}$, and it has been found at high allele frequency in the Spanish population (minor allele frequency $=0.012)^{115}$, but at low frequency in other European populations. This allele has been reported to affect the metabolism of clozapine, also associated with treatment-resistant SCZ ${ }^{116}$.

In relation to carriage of damaging variants in neurodevelopmental genes that could affect SCZ and cognitive ability, two patients diagnosed with SCZ were carriers of the DISC1 missense rare variant (p.Arg418His) and clearly manifested a cognitive disability. DISC1 gene has been involved in the neurodevelopmental process and the development of normal cognitive function ${ }^{31}$. The product of this gene is greatly involved in brain cortex development, including symmetry and orientation of neurons ${ }^{117-120}$. Furthermore, a common variation in the DISC1 gene has been associated with Alzheimer's disease, reinforcing the notion that this gene could have a strong effect on cognitive development.

An interesting finding was that $A B C C 1$ (ATP-binding cassette, subfamily $C$, and member 1 gene) was the only gene where two patients in each group shared a variant. The patient diagnosed with DAT who was a carrier of the $A B C C 1$ variant had a rapid cognitive decline, with severe manifestations of cognitive impairment. Likewise, the patient diagnosed with SCZ and was a carrier of a variant in this gene had a cognitive disability, mainly affecting memory function. $A B C C 1$ has previously been implicated in the increased accumulation of amyloid- $\beta$, dependent on its expression in a mouse model of early Alzheimer's disease ${ }^{121}$. However, the effect of the observed novel and rare damaging variants in disease etiology would be under the scope of future studies. The development of NGS technologies has enabled the screening of many genetic variants, finding a large number that has not been previously reported. The substantial number of $\mathrm{Nv}$ found makes impractical to functionally validate each one; in this sense, computer methods have been developed to anticipate the effect of a variant at the molecular level. Here, we presented a sequencing data analysis utilizing different algorithms to prioritize the damaging effect of variants. We focused on those with a higher impact on disease etiology, based on distinct algorithms.

Our results may be limited by the small sample size; however, we explored genetic variation in 184 genes previously associated with neurodegenerative diseases and drug treatment. We located some rare and novel damaging variants on 18 genes formerly known to be involved in neuropsychiatric disorders in a Mexican population, and we discussed their potential role in these diseases. Future endeavors should focus on validating these observations.

\section{ACKNOWLEDGMENTS}

This work was supported by funding from the National Institute of Genomic Medicine to the Laboratory of Genomics of Psychiatric and Neurodegenerative Diseases, project IMG/DI/136/2014. The technical expertise of Alfredo Mendoza Vargas from the NGS unit is gratefully acknowledged.

\section{SUPPLEMENTARY DATA}

Supplementary data are available at Revista de Investigación Clínica online (www.clinicalandtranslationalinvestigation.com). These data are provided by the corresponding author and published online for the benefit of the reader. The contents of supplementary data are the sole responsibility of the authors.

\section{REFERENCES}

1. Ngui EM, Khasakhala L, Ndetei D, Roberts LW. Mental disorders, health inequalities and ethics: a global perspective. Int Rev Psychiatry. 2010;22:235-44.

2. Murray CJ, Vos T, Lozano R, Naghavi M, Flaxman AD, Michaud $C$, et al. Disability-adjusted life years (DALYs) for 291 diseases and injuries in 21 regions, 1990-2010: a systematic analysis for the global burden of disease study 2010. Lancet. 2012; 380:2197-223

3. Vigo D, Thornicroft G, Atun R. Estimating the true global burden of mental illness. Lancet Psychiatry. 2016;3:171-8.

4. Chaudhury PK, Deka K, Chetia D. Disability associated with mental disorders. Indian J Psychiatry. 2006;48:95-101.

5. Ribe AR, Laursen TM, Charles M, Katon W, Fenger-Grøn M Davydow D, et al. Long-term risk of dementia in persons with schizophrenia: a danish population-based cohort study. JAMA Psychiatry. 2015;72:1095-101. 
6. Lambert JC, Ibrahim-Verbaas CA, Harold D, Naj AC, Sims R, Bellenguez $C$, et al. Meta-analysis of 74,046 individuals identifies 11 new susceptibility loci for alzheimer's disease. Nat Genet. 2013:45:1452-8

7. Schizophrenia Working Group of the Psychiatric Genomics Consortium. Biological insights from 108 schizophrenia-associated genetic loci. Nature. 2014;511:421-7.

8. MacArthur DG, Manolio TA, Dimmock DP, Rehm HL, Shendure J, Abecasis GR, et al. Guidelines for investigating causality of sequence variants in human disease. Nature. 2014;508:469-76.

9. Eichler EE, Flint J, Gibson G, Kong A, Leal SM, Moore JH, et al. Missing heritability and strategies for finding the underlying causes of complex disease. Nat Rev Genet. 2010;11:446-50.

10. Nelson MR, Wegmann D, Ehm MG, Kessner D, St Jean P, Verzilli C, et al. An abundance of rare functional variants in 202 drug target genes sequenced in 14,002 people. Science. 2012;337:100-4.

11. Mathieson I, Reich D. Differences in the rare variant spectrum among human populations. PLoS Genet. 2017:13:e1006581.

12. Romero-Hidalgo S, Ochoa-Leyva A, Garcíarrubio A, AcuñaAlonzo V, Antúnez-Argüelles E, Balcazar-Quintero M, et al. Demographic history and biologically relevant genetic variation of native Mexicans inferred from whole-genome sequencing. Nat Commun. 2017;8:1005

13. Chagas MH, Pessoa RM, Almeida OP. Comparison of DSM-IV and DSM-5 dementia criteria among older people living in a community sample. Int J Geriatr Psychiatry. 2018;33:801-2.

14. Folstein MF, Folstein SE, McHugh PR. "Mini-mental state". A practical method for grading the cognitive state of patients for the clinician. J Psychiatr Res. 1975:12:189-98.

15. Ostrosky-Solis F, Esther Gomez-Perez M, Matute E, Rosselli M, Ardila A, Pineda D, et al. Neuropsi attention and memory: a neuropsychological test battery in spanish with norms by age and educational level. Appl Neuropsychol. 2007;14:156-70.

16. Pato MT, Sobell JL, Medeiros H, Abbott C, Sklar BM, Buckley PF, et al. The genomic psychiatry cohort: partners in discovery. Am J Med Genet B Neuropsychiatr Genet. 2013;162B:306-12.

17. Aprahamian I, Martinelli JE, Neri AL, Yassuda MS. The clock drawing test: a review of its accuracy in screening for dementia. Dement Neuropsychol. 2009:3:74-81.

18. O'Bryant SE, Waring SC, Cullum CM, Hall J, Lacritz L, Massman $\mathrm{PJ}$, et al. Staging dementia using clinical dementia rating scale sum of boxes scores: a Texas alzheimer's research consortium study. Arch Neurol. 2008;65:1091-5.

19. Zimmerman M, Chelminski I. A scale to screen for DSM-IV axis I disorders in psychiatric out-patients: performance of the psychiatric diagnostic screening questionnaire. Psychol Med. 2006; 36:1601-11.

20. McKhann GM, Knopman DS, Chertkow H, Hyman BT, Jack CR Jr., Kawas $\mathrm{CH}$, et al. The diagnosis of dementia due to alzheimer's disease: recommendations from the national institute on agingalzheimer's association workgroups on diagnostic guidelines for alzheimer's disease. Alzheimers Dement. 2011:7:263-9.

21. Nurnberger JI Jr., Blehar MC, Kaufmann CA, York-Cooler C, Simpson SG, Harkavy-Friedman J, et al. Diagnostic interview for genetic studies. Rationale, unique features, and training. NIMH genetics initiative. Arch Gen Psychiatry. 1994:51:849-59.

22. Regier DA, Kuhl EA, Kupfer DJ. The DSM-5: classification and criteria changes. World Psychiatry. 2013;12:92-8.

23. Lally J, Gaughran F, Timms P, Curran SR. Treatment-resistant schizophrenia: current insights on the pharmacogenomics of antipsychotics. Pharmgenomics Pers Med. 2016;9:117-29.

24. Andreasen NC. Methods for assessing positive and negative symptoms. Mod Probl Pharmacopsychiatry. 1990;24:73-88.

25. Genis-Mendoza AD, Martínez-Magaña JJ, Bojórquez C, TéllezMartínez JA, Jiménez-Genchi J, Roche A, et al. Programa de detección del alelo APOE-E4 en adultos mayores mexicanos con deterioro cognitivo. Gac Med Mex 2018:154.555-60.

26. Giacopuzzi E, Gennarelli M, Minelli A, Gardella R, Valsecchi $P$, Traversa $\mathrm{M}$, et al. Exome sequencing in schizophrenic patients with high levels of homozygosity identifies novel and extremely rare mutations in the GABA/glutamatergic pathways. PLoS One. 2017;12:e0182778

27. Guipponi M, Santoni FA, Setola V, Gehrig C, Rotharmel M, Cuenca $\mathrm{M}$, et al. Exome sequencing in 53 sporadic cases of schizophrenia identifies 18 putative candidate genes. PLoS One. 2014; 9:e112745

28. Rafaniello C, Sessa M, Bernardi FF, Pozzi M, Cheli S, Cattaneo D, et al. The predictive value of $A B C B 1, A B C G 2, C Y P 3 A 4 / 5$ and CYP2D6 polymorphisms for risperidone and aripiprazole plasma concentrations and the occurrence of adverse drug reactions. Pharmacogenomics J. 2018;18:422-30.
29. Cacabelos R. Pharmacogenomics of alzheimer's and parkinson's diseases. Neurosci Lett. 2018;18:S0304-3940(18):30624-4.

30. Cacabelos R, Meyyazhagan A, Carril JC, Cacabelos P, Teijido Ó Pharmacogenetics of vascular risk factors in alzheimer's disease. J Pers Med. 2018;8:E3.

31. Singh KK, De Rienzo G, Drane L, Mao Y, Flood Z, Madison J, et al. Common DISC1 polymorphisms disrupt wnt/GSK3 $\beta$ signaling and brain development. Neuron. 2011;72:545-58.

32. Nguyen HT, Bryois J, Kim A, Dobbyn A, Huckins LM, MunozManchado $A B$, et al. Integrated bayesian analysis of rare exonic variants to identify risk genes for schizophrenia and neurodevelopmental disorders. Genome Med. 2017;9:114.

33. Butkiewicz M, Blue EE, Leung YY, Jian X, Marcora E, Renton AE, et al. Functional annotation of genomic variants in studies of lateonset alzheimer's disease. Bioinformatics. 2018;34:2724-31.

34. Zai CC, Tiwari AK, Zai GC, Maes MS, Kennedy JL. New findings in pharmacogenetics of schizophrenia. Curr Opin Psychiatry. 2018:31:200-12.

35. Lord J, Lu AJ, Cruchaga C. Identification of rare variants in alzheimer's disease. Front Genet. 2014;5:369.

36. Raghavan NS, Brickman AM, Andrews H, Manly JJ, Schupf N, Lantigua $\mathrm{R}$, et al. Whole-exome sequencing in 20,197 persons for rare variants in alzheimer's disease. Ann Clin Transl Neurol. 2018;5:832-42.

37. Gonzalez-Covarrubias V Urena-Carrion J, Villegas-Torres B Cossío-Aranda JE, Trevethan-Cravioto S, Izaguirre-Avila R, et al. Pharmacogenetic variation in over 100 genes in patients receiving acenocumarol. Front Pharmacol. 2017:8:863.

38. Bolger AM, Lohse M, Usadel B. Trimmomatic: a flexible trimmer for illumina sequence data. Bioinformatics. 2014;30:2114-20.

39. Li H, Durbin R. Fast and accurate short read alignment with burrows-wheeler transform. Bioinformatics. 2009:25:1754-60.

40. Lander ES, Linton LM, Birren B, Nusbaum C, Zody MC, Baldwin J, et al. Initial sequencing and analysis of the human genome. Nature. 2001:409:860-921.

41. DePristo MA, Banks E, Poplin R, Garimella KV, Maguire JR, Hartl $C$, et al. A framework for variation discovery and genotyping using next-generation DNA sequencing data. Nat Genet. 2011; 43:491-8

42. Van der Auwera GA, Carneiro MO, Hartl C, Poplin R, Del Angel $\mathrm{G}$, Levy-Moonshine A, et al. From fastQ data to high confidence variant calls: the genome analysis toolkit best practices pipeline. Curr Protoc Bioinformatics. 2013;43:11.10.1-33

43. Fromer M, Purcell SM. Using XHMM software to detect copy number variation in whole-exome sequencing data. Curr Protoc Hum Genet. 2014:81:7.23.1-21.

44. Robinson JT, Thorvaldsdóttir H, Winckler W, Guttman M, Lander ES, Getz G, et al. Integrative genomics viewer. Nat Biotechnol. 2011;29:24-6.

45. McLaren W, Gil L, Hunt SE, Riat HS, Ritchie GR, Thormann A, et al. The ensembl variant effect predictor. Genome Biol. 2016; $17: 122$

46. Landrum MJ, Lee JM, Riley GR, Jang W, Rubinstein WS, Church $\mathrm{DM}$, et al. ClinVar: public archive of relationships among sequence variation and human phenotype. Nucleic Acids Res. 2014:42:D980-5

47. Kobayashi Y, Yang S, Nykamp K, Garcia J, Lincoln SE, Topper SE, et al. Pathogenic variant burden in the exAC database: an empirical approach to evaluating population data for clinical variant interpretation. Genome Med. 2017:9:13.

48. 1000 Genomes Project Consortium, Auton A, Brooks LD, Durbin RM, Garrison EP, Kang HM, et al. A global reference for human genetic variation. Nature. 2015:526:68-74.

49. Ng PC, Henikoff S. SIFT: predicting amino acid changes that affect protein function. Nucleic Acids Res. 2003;31:3812-4.

50. Adzhubei I, Jordan DM, Sunyaev SR. Predicting functional effect of human missense mutations using polyPhen-2. Curr Protoc Hum Genet. 2013; Chapter 7:Unit7.20.

51. Kircher M, Witten DM, Jain P, O'Roak BJ, Cooper GM, Shendure J, et al. A general framework for estimating the relative pathogenicity of human genetic variants. Nat Genet. 2014;46:310-5.

52. Rogers MF, Shihab HA, Mort M, Cooper DN, Gaunt TR, Campbell $C$, et al. FATHMM-XF: accurate prediction of pathogenic point mutations via extended features. Bioinformatics. 2018. 34:511-3

53. Hamosh A, Scott AF, Amberger J, Bocchini C, Valle D, McKusick $V A$, et al. Online mendelian inheritance in man (OMIM), a knowledgebase of human genes and genetic disorders. Nucleic Acids Res. 2002;30:52-5

54. Wildeman M, van Ophuizen E, den Dunnen JT, Taschner PE. Improving sequence variant descriptions in mutation databases 
and literature using the mutalyzer sequence variation nomenclature checker. Hum Mutat. 2008;29:6-13.

55. Zweier C, de Jong EK, Zweier M, Orrico A, Ousager LB, Collins $A L$, et al. CNTNAP2 and NRXN1 are mutated in autosomal-recessive pitt-hopkins-like mental retardation and determine the level of a common synaptic protein in drosophila. Am J Hum Genet. 2009;85:655-66.

56. Harrison V, Connell L, Hayesmoore J, McParland J, Pike MG, Blair $\mathrm{E}$, et al. Compound heterozygous deletion of NRXN1 causing severe developmental delay with early onset epilepsy in two sisters. Am J Med Genet A. 2011;155A:2826-31.

57. Curran ME, Splawski I, Timothy KW, Vincent GM, Green ED, Keating MT, et al. A molecular basis for cardiac arrhythmia: HERG mutations cause long QT syndrome. Cell. 1995;80:795-803.

58. Zhou Z, Gong Q, Epstein ML, January CT. HERG channel dysfunction in human long QT syndrome. Intracellular transport and functional defects. J Biol Chem. 1998;273:21061-6.

59. Jiang YC, Wu HM, Cheng KH, Sun HS. Menstrual cycle-dependent febrile episode mediated by sequence-specific repression of poly(ADP-ribose) polymerase-1 on the transcription of the human serotonin receptor 1 A gene. Hum Mutat. 2012:33:209-17.

60. Fazzari P, Paternain AV, Valiente M, Pla R, Luján R, Lloyd K, et al. Control of cortical GABA circuitry development by nrg 1 and erbB4 signalling. Nature. 2010;464:1376-80.

61. Feng J, Schroer R, Yan J, Song W, Yang C, Bockholt A, et al. High frequency of neurexin 1 beta signal peptide structural variants in patients with autism. Neurosci Lett. 2006;409:10-3

62. Autism Genome Project Consortium, Szatmari P, Paterson AD Zwaigenbaum L, Roberts W, Brian J, et al. Mapping autism risk loci using genetic linkage and chromosomal rearrangements. Nat Genet. 2007:39:319-28.

63. Yan J, Noltner K, Feng J, Li W, Schroer R, Skinner C, et al. Neurexin 1 alpha structural variants associated with autism. Neurosci Lett. 2008;438:368-70

64. Kim HG, Kishikawa S, Higgins AW, Seong IS, Donovan DJ, Shen $Y$, et al. Disruption of neurexin 1 associated with autism spectrum disorder. Am J Hum Genet. 2008;82:199-207.

65. Gauthier J, Siddiqui TJ, Huashan P, Yokomaku D, Hamdan FF, Champagne $\mathrm{N}$, et al. Truncating mutations in NRXN2 and NRXN1 in autism spectrum disorders and schizophrenia. Hum Genet. 2011;130:563-73.

66. Apud JA, Zhang F, Decot H, Bigos KL, Weinberger DR. Genetic variation in KCNH2 associated with expression in the brain of a unique hERG isoform modulates treatment response in patients with schizophrenia. Am J Psychiatry. 2012;169:725-34.

67. Hashimoto R, Ohi K, Yasuda Y, Fukumoto M, Yamamori $\mathrm{H}, \mathrm{Ka}$ mino $\mathrm{K}$, et al. The $\mathrm{KCNH} 2$ gene is associated with neurocognition and the risk of schizophrenia. World J Biol Psychiatry. 2013:14:114-20.

68. Huffaker SJ, Chen J, Nicodemus KK, Sambataro F, Yang F, Mattay $\mathrm{V}$, et al. A primate-specific, brain isoform of $\mathrm{KCNH} 2$ affects cortical physiology, cognition, neuronal repolarization and risk of schizophrenia. Nat Med. 2009;15:509-18.

69. Zuo L, Zhang XY, Wang F, Li CS, Lu L, Ye L, et al. Genome-wide significant association signals in IPO11-HTR1A region specific for alcohol and nicotine codependence. Alcohol Clin Exp Res. 2013;37:730-9.

70. Zuo L, Saba L, Lin X, Tan Y, Wang K, Krystal JH, et al. Significant association between rare IPO11-HTR1A variants and attention deficit hyperactivity disorder in caucasians. Am J Med Genet B Neuropsychiatr Genet. 2015;168:544-56.

71. Gonzalez-Covarrubias V, Zhang J, Kalabus JL, Relling MV, Blanco JG. Pharmacogenetics of human carbonyl reductase 1 (CBR1) in livers from black and white donors. Drug Metab Dispos. 2009;37:400-7

72. Gonzalez-Covarrubias V, Kalabus JL, Blanco JG. Inhibition of polymorphic human carbonyl reductase 1 (CBR1) by the cardioprotectant flavonoid 7-monohydroxyethyl rutoside (monoHER). Pharm Res. 2008;25:1730-4.

73. Hipfner DR, Deeley RG, Cole SP. Structural, mechanistic and clinical aspects of MRP1. Biochim Biophys Acta. 1999;1461: 359-76.

74. Chang XB. A molecular understanding of ATP-dependent solute transport by multidrug resistance-associated protein MRP1. Cancer Metastasis Rev. 2007;26:15-37.

75. Choudhuri S, Klaassen CD. Structure, function, expression, genomic organization, and single nucleotide polymorphisms of human ABCB1 (MDR1), ABCC (MRP), and ABCG2 (BCRP) efflux transporters. Int J Toxicol. 2006;25:231-59.

76. Sharom FJ. ABC multidrug transporters: structure, function and role in chemoresistance. Pharmacogenomics. 2008;9:105-27.
77. Mohler PJ, Schott J], Gramolini AO, Dilly KW, Guatimosim S duBell WH, et al. Ankyrin-B mutation causes type 4 long-QT cardiac arrhythmia and sudden cardiac death. Nature. 2003. 421:634-9.

78. Mohler PJ, Splawski I, Napolitano C, Bottelli G, Sharpe L, Timothy $K$, et al. A cardiac arrhythmia syndrome caused by loss of ankyrin-B function. Proc Natl Acad Sci U S A. 2004;101:9137-42.

79. Impagnatiello F, Guidotti AR, Pesold C, Dwivedi $Y$, Caruncho $H$, Pisu MG, et al. A decrease of reelin expression as a putative vulnerability factor in schizophrenia. Proc Natl Acad Sci U S A. 1998;95:15718-23

80. Hong SE, Shugart YY, Huang DT, Shahwan SA, Grant PE, Hourihane JO, et al. Autosomal recessive lissencephaly with cerebellar hypoplasia is associated with human RELN mutations. Nat Genet. 2000;26:93-6

81. Dazzo E, Fanciulli M, Serioli E, Minervini G, Pulitano P, Binelli $S$, et al. Heterozygous reelin mutations cause autosomaldominant lateral temporal epilepsy. Am J Hum Genet. 2015; 96:992-1000

82. Morrow JA, Collie IT, Dunbar DR, Walker GB, Shahid M, Hill DR, et al. Molecular cloning and functional expression of the human glycine transporter glyT2 and chromosomal localisation of the gene in the human genome. FEBS Lett. 1998;439:334-40.

83. López-Corcuera B, Arribas-González E, Aragón C. Hyperekplexia-associated mutations in the neuronal glycine transporter 2. Neurochem Int. 2019;123:95-100.

84. Goyette P, Sumner JS, Milos R, Duncan AM, Rosenblatt DS, Matthews RG, et al. Human methylenetetrahydrofolate reductase: isolation of cDNA, mapping and mutation identification. Nat Genet. 1994;7:195-200.

85. Lemke JR, Hendrickx R, Geider K, Laube B, Schwake M, Harvey RJ, et al. GRIN2B mutations in west syndrome and intellectual disability with focal epilepsy. Ann Neurol. 2014;75:147-54.

86. Endele S, Rosenberger G, Geider K, Popp B, Tamer C, Stefanova I, et al. Mutations in GRIN2A and GRIN2B encoding regulatory subunits of NMDA receptors cause variable neurodevelopmental phenotypes. Nat Genet. 2010;42:1021-6.

87. O'Roak BJ, Deriziotis P, Lee C, Vives L, Schwartz JJ, Girirajan S, et al. Exome sequencing in sporadic autism spectrum disorders identifies severe de novo mutations. Nat Genet. 2011;43:585-9.

88. Platzer K, Yuan H, Schütz H, Winschel A, Chen W, Hu C, et al. GRIN2B encephalopathy: novel findings on phenotype, variant clustering, functional consequences and treatment aspects. J Med Genet. 2017;54:460-70.

89. Winham SJ, Cuellar-Barboza AB, McElroy SL, Oliveros A, Crow S Colby $C L$, et al. Bipolar disorder with comorbid binge eating history: a genome-wide association study implicates APOB. J Affect Disord. 2014;165:151-8.

90. Chen N, Bao Y, Xue Y, Sun Y, Hu D, Meng S, et al. Meta-analyses of RELN variants in neuropsychiatric disorders. Behav Brain Res. 2017;332:110-9

91. Fehér Á, Juhász A, Pákáski M, Kálmán J, Janka Z. Genetic analysis of the RELN gene: gender specific association with alzheimer's disease. Psychiatry Res. 2015;230:716-8.

92. Bufill E, Roura-Poch P, Sala-Matavera I, Antón S, Lleó A, SánchezSaudinós $B$, et al. Reelin signaling pathway genotypes and alzheimer disease in a spanish population. Alzheimer Dis Assoc Disord. 2015;29:169-72

93. Liu F, Arias-Vásquez A, Sleegers K, Aulchenko YS, Kayser M, Sanchez-Juan $P$, et al. A genomewide screen for late-onset alzheimer disease in a genetically isolated dutch population. Am J Hum Genet. 2007;81:17-31.

94. Hennah W, Varilo T, Kestilä M, Paunio T, Arajärvi R, Haukka J, et al. Haplotype transmission analysis provides evidence of association for DISC1 to schizophrenia and suggests sex-dependent effects. Hum Mol Genet. 2003;12:3151-9.

95. Hodgkinson CA, Goldman D, Jaeger J, Persaud S, Kane JM, Lipsky RH, et al. Disrupted in schizophrenia 1 (DISC1): association with schizophrenia, schizoaffective disorder, and bipolar disorder. Am J Hum Genet. 2004;75:862-72.

96. Coppedè F, Tannorella P, Pezzini I, Migheli F, Ricci G, Caldarazzo lenco $E$, et al. Folate, homocysteine, vitamin B12, and polymorphisms of genes participating in one-carbon metabolism in lateonset alzheimer's disease patients and healthy controls. Antioxid Redox Signal. 2012;17:195-204.

97. Pitcher GM, Kalia LV, Ng D, Goodfellow NM, Yee KT, Lambe EK, et al. Schizophrenia susceptibility pathway neuregulin 1-erbB4 suppresses src upregulation of NMDA receptors. Nat Med. 2011;17:470-8.

98. Deng X, Sagata N, Takeuchi N, Tanaka M, Ninomiya H, Iwata N et al. Association study of polymorphisms in the neutral amino 
acid transporter genes SLC1A4, SLC1A5 and the glycine transporter genes SLC6A5, SLC6A9 with schizophrenia. BMC Psychiatry. 2008;8:58

99. Motulsky AG. Nutritional ecogenetics: homocysteine-related arteriosclerotic vascular disease, neural tube defects, and folic acid. Am J Hum Genet. 1996;58:17-20.

100. Stevenson RE, Schwartz CE, Du YZ, Adams MJ Jr. Differences in methylenetetrahydrofolate reductase genotype frequencies, between whites and blacks. Am J Hum Genet. 1997;60:229-30.

101. Bjelland I, Tell GS, Vollset SE, Refsum H, Ueland PM. Folate, vitamin B12, homocysteine, and the MTHFR 677C->T polymorphism in anxiety and depression: the hordaland homocysteine study. Arch Gen Psychiatry. 2003;60:618-26.

102. Lewis SJ, Lawlor DA, Smith GD, Araya R, Timpson N, Day IN, et al. The thermolabile variant of MTHFR is associated with depression in the British women's heart and health study and a meta-analysis. Mol Psychiatry. 2006;11:352-60

103. Takasaki Y, Koide T, Wang C, Kimura H, Xing J, Kushima I, et al. Mutation screening of GRIN2B in schizophrenia and autism spectrum disorder in a japanese population. Sci Rep. 2016; 6:33311.

104. Hahn CG, Wang HY, Cho DS, Talbot K, Gur RE, Berrettini WH, et al. Altered neuregulin 1-erbB4 signaling contributes to NMDA receptor hypofunction in schizophrenia. Nat Med. 2006;12:824-8.

105. Lutz SM, Frederiksen B, Begum F McDonald MN, Cho MH, Hobbs $\mathrm{BD}$, et al. Common and rare variants genetic association analysis of cigarettes per day among ever-smokers in chronic obstructive pulmonary disease cases and controls. Nicotine Tob Res. 2019;21:714-22.

106. Del Monte-Nieto G, Ramialison M, Adam AA, Wu B, Aharonov A, D'Uva G, et al. Control of cardiac jelly dynamics by NOTCH1 and NRG1 defines the building plan for trabeculation. Nature. 2018;557:439-45

107. Li B, Woo RS, Mei L, Malinow R. The neuregulin-1 receptor erbB4 controls glutamatergic synapse maturation and plasticity. Neuron. 2007:54:583-97.

108. Rodrigues-Amorim D, Rivera-Baltanás T, Bessa J, Sousa N, Vallejo-Curto MC, Rodríguez-Jamardo $C$, et al. The neurobiological hypothesis of neurotrophins in the pathophysiology of schizophrenia: a meta-analysis. J Psychiatr Res. 2018;106:43-53.

109. Vélez JI, Lopera F, Patel HR, Johar AS, Cai Y, Rivera D, et al. Mutations modifying sporadic alzheimer's disease age of onset. Am J Med Genet B Neuropsychiatr Genet. 2016;171:1116-30.
110. Asarnow RF, Forsyth JK Genetics of childhood-onset schizophrenia. Child Adolesc Psychiatr Clin N Am. 2013;22:675-87.

111. Chaumette B, Ferrafiat V, Ambalavanan A, Goldenberg A, Dionne-Laporte A, Spiegelman D, et al. Missense variants in ATP1A3 and FXYD gene family are associated with childhood-onset schizophrenia. Mol Psychiatry. 2018; volume 23.

112. Sting| JC, Brockmöller J, Viviani R. Genetic variability of drugmetabolizing enzymes: the dual impact on psychiatric therapy and regulation of brain function. Mol Psychiatry. 2013;18: 273-87.

113. Toselli F, Dodd PR, Gillam EM. Emerging roles for brain drugmetabolizing cytochrome P450 enzymes in neuropsychiatric conditions and responses to drugs. Drug Metab Rev. 2016 48:379-404

114. Westlind-Johnsson A, Hermann R, Huennemeyer A, Hauns B Lahu $G$, Nassr $N$, et al. Identification and characterization of CYP3A4*20, a novel rare CYP3A4 allele without functional activity. Clin Pharmacol Ther. 2006;79:339-49.

115. Apellániz-Ruiz M, Inglada-Pérez L, Naranjo ME, Sánchez L, Mancikova V, Currás-Freixes $M$, et al. High frequency and founder effect of the CYP3A4*20 loss-of-function allele in the spanish population classifies CYP3A4 as a polymorphic enzyme. Pharmacogenomics J. 2015;15:288-92.

116. Tóth K, Csukly G, Sirok D, Belic A, Kiss Á, Háfra E, et al. Potential role of patients' CYP3A-status in clozapine pharmacokinetics. Int J Neuropsychopharmacol. 2017;20:529-37.

117. Zhang XY, Wang HF, Tan MS, Wan Y, Kong LL, Zheng ZJ, et al. Association of DISC1 polymorphisms with late-onset alzheimer's disease in northern han chinese. Mol Neurobiol. 2017;54: 2922-7.

118. Kamiya A, Kubo K, Tomoda T, Takaki M, Youn R, Ozeki Y, et al. A schizophrenia-associated mutation of DISC1 perturbs cerebral cortex development. Nat Cell Biol. 2005;7:1167-78.

119. St Clair D, Blackwood D, Muir W, Carothers A, Walker M, Spowart G, et al. Association within a family of a balanced autosomal translocation with major mental illness. Lancet. 1990;336:13-6.

120. Zhou Z, Hu Z, Zhang L, Hu Z, Liu H, Liu Z, et al. Identification of RELN variation p.Thr3192Ser in a chinese family with schizophrenia. Sci Rep. 2016;6:24327.

121. Krohn M, Bracke A, Avchalumov Y, Schumacher T, Hofrichter J, Paarmann $K$, et al. Accumulation of murine amyloid- $\beta$ mimics early alzheimer's disease. Brain. 2015;138:2370-82. 